\title{
Doktrina: Journal of Law
}

Available online http://ojs.uma.ac.id/index.php/doktrina

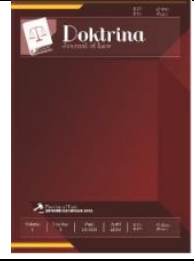

Kedudukan Saksi Non Muslim Dalam Pandangan Islam dan Kitab Undang-Undang Hukum Acara Perdata Sebagai Alat Bukti Berperkara di Pengadilan Agama

\section{Position of Non-Muslim Witnesses in the Islamic View and The Civil Procedure Code as a Proof of Evidence in the Religious Court}

\author{
Anto Mutriady Lubis* \\ Prodi Ilmu Hukum, Fakultas Hukum, Universitas Amir Hamzah, Indonesia
}

*Coresponding Email: lubisantomutriady@ymail.com

\begin{abstract}
Abstrak
Peradilan agama memiliki peran penting khususnya bagi penyelesaian perkara perdata islam bagi orangorang islam. Di dalam pembuktian di peradilan agama khususnya saksi perlu ada kejelasan tentang kedudukan saksi non muslim yang sama dengan saksi muslim yaitu sebagai salah satu alat bukti dalam pembuktian di persidangan perkara peradilan agama, guna untuk menguatkan dalil-dalil para pihak yang berpekara. Kekuatan pembuktian saksi non muslim di pengadilan agama harus secara jelas aturan yang mengatur tentang kedudukan saksi non muslim dalam berperkara di pengadilan. Hal ini menimbang adanya pembauran antara masyarakat muslim dengan penganut masyarakat non muslim. Sehingga tidak menutup kemungkinan penganut non muslim menjadi saksi di muka pengadilan Agama yang dapat membantu menyelesaikan suatu perkara di pengadilan agama.
\end{abstract}

Kata Kunci: Saksi Non Muslim, Alat Bukti, Pengadilan Agama

\begin{abstract}
Religious justice has an important role especially for the settlement of Islamic civil cases for Muslims. In the evidence in the religious court, especially witnesses, there needs to be clarity about the position of nonMuslim witnesses who are the same as Muslim witnesses, namely as one of the evidences in the evidence in the trial of the religious court case, in order to strengthen the arguments of the parties who are involved. The strength of proving non-Muslim witnesses in religious courts must clearly state the rules governing the position of non-Muslim witnesses in litigation in court. This considers the intermingling between Muslim communities and adherents of non-Muslim communities. So it does not rule out the possibility of nonMuslim adherents being witnesses before the Religious court who can help resolve a case in the religious court.
\end{abstract}

\section{Keywords: Non Muslim Witness, Evidence Tool, Religious Court}

How to Cite: Lubis, A.M. (2018). Kendudukan Saksi Non Muslim Dalam Pandangan Islam dan Kitab UndangUndang Hukum Acara Perdata Sebagai Alat Bukti Berperkara di Pengadilan Agama. Doktrina: Journal of Law. 1 (2): 144-153 


\section{PENDAHULUAN}

Adanya saksi non muslim yang diakibatkan pembauran antara masyarakat muslim dengan penganut masyarakat non muslim, hal ini berkaitan dengan hubungan social di masyarakat dan tidak terlepas persoalan seseorang sebagai warga masyarakat yang mempunyai hubungan dekat dengan warga lainnya khususny tetangga. Bila seseorang berperkara cerai di pengadilan agama tentunya pihak yang dapat di mintai keterangan saksi orang yang betul-betul mengetahui sehari-sehari bila seseorang terjadi persoalan dalam rumah tangganya, tentunya pihak yang di mintai jadi saksi itu salah satunya ialah tetangganya. Andaikan tetangganya yang dekat dengan berperkara adalah non muslim, maka seharusnyalah dapat menjadi saksi bagi seseorang berperkara di pengadilan agama, karena dia lebih dekat dan mengetahui adanya persoalan dalam rumah tangga.

Peran peradilan agama sangat penting dalam menyelesaikan perselisihan antara orang yang beragama islam dalam hal berkaitan dengan persolan yang terkait dalam perdata islam. Pada awalnya peran peradilan agama merupakan pengadilan tingkat pertama untuk memeriksa, memutus dan menyelesaikan perkaraperkara orang yang beragama islam di bidang perkawinan, kewarisan, wasiat, hibah, wakaf dan sedekah berdasarkan hukum islam sebagaimana yang di jelaskan dalam Pasal 2 dan 49 Undang-Undang No. 7 Tahun 1989.

Bila dilihat dari Pasal 2 dan 49 Undang-Undang Nomor 7 Tahun 1989 dapat di jelaskan bahwa undang-undang ini semata-mata di khususkan bagi para pihak yang beragama islam dalam berperkara di peradilan agama. Pada hal dalam kaitan dengan hubungan social di masyarakat bisa saja pihak yang beperkara di peradilan agama berkaitan dengan pihak di luar agama Islam.

Dalam hal perkembangan sosial dimasyarakat menjadikan Undang-Undang Nomr 7 Tahun 1989 yang akhirnya direvisi pada tanggal 20 Maret Tahun 2006 merubah Undang-Undang Nomor 7 Tahun 1989 tentang Peradilan Agama menjadi Undang-Undang Nomor 3 Tahun 2006 tentang peradilan agama. Di dalam ketentuan undang-undang Nomor 3 Tahun 2006 ini dapat di berikan pengertian orang-orang non muslim mengikatkan dirinya dalam perjanjian-perjanjian yang menggunakan dasar hukum syariah juga termasuk kompetensi pengadilan agama. Misalnya seorang non muslim menginvestasikan hartanya pada reksa dana syariah, maka antara orang muslim 
tadi dengan pihak pengelola reksa dana syariah terikat dalam perjanjianyang telaah mereka sepakati bersama. Apabila di kemudian hari timbul sengketa non muslim tadi berhak mengajukan gugatan ke pengadilan agama. (Abd Somad, 2010).

Masih di pakainya sumber hukum acara perdata khususnya menyangkut alat bukti saksi dalam peradilan agama, dapat memungkinkan saksi dari non muslim dalam memberikan pembuktian di peradilan agama. Hal ini sebagaimana di sebutkan pasal 54 Undang-Undang Nomor 3 Tahun 2006 sebagaimana yang telah di ubah dengan Undang-Undang Nomor 50 Tahun 2009 tentang peradilan agama yang menyatakan bahwa hukum hukum acara yang berlaku di pengadilan agama adalah hukum acara perdata yang berlaku di pengadilan umum.

Sedangkan dalam hukum acara perdata tidak menentukan saksi dari latar belakang agama, akan tetapi dalam hukum acara perdata bahwa kesaksian adalah kepastian yang di berikan hakim di persidangan tentang peristiwa yang di sengketakan dengan jalan pemberitahuan secara lisaan dan pribadi oleh orang yang bukan salah satu pihak dalam perkara yang di panggil dalam persidangan.

Jadi yang menjadi permasalahan terhadap persoalan saksi non muslim dalam beracara di peradilan agama adalah menyangkut kejelasan kedudukannya sebagai alat bukti yang sesuai dengan hukum acara perdata maupun dari segi pandangan islam agar tidak terjadi perbedaan pandangan menyangkut kedudukan saksi non muslim.

Dalam tulisan ini, akan membahas pandangan Islam terhadap saksi non muslim berperkara di Pengadilan Agama dan saksi non muslim menurut hukum acara perdata.

\section{METODE PENELITIAN}

Sebagai sebuah penelitian ilmiah, maka rangkaian kegiatan penelitian mulai dari pengumpulan data sampai pada analisis data dilakukan dengan memperhatikan kaidah-kaidah penelitian ilmiah, sebagai berikut:

1. Jenis Penelitian

Jenis penelitian ini dilakukan dengan metode penelitian yuridis normatif atau penelitian hukum kepustakaan yaitu metode atau cara yang digunakan di dalam penelitian hukum yang dilakukan dengan cara meneliti bahan pustaka yang ada (Soekanto dan Mamudji, 2009).

2. Sumber Data

Sumber data penelitian yang digunakan merupakan data sekunder yang terdiri dari:

a) Bahan hukum primer, yang terdiri dari 
Peraturan perundang-undangan yang berkaitan dengan objek penelitian, yaitu Undang-Undang Nomor 7 Tahun 1989 dirubah menjadi Undang-Undan Nomor 3 Tahun 2006 perubahan kedua menjadi Undang-Undang Nomor 50 Tahun 2009 tentang Peradilan Agama dan penjelasannya, HIR dan RBG serta Kitab Undang-Undang Hukum Perdata (KUH Perdata).

b) Bahan Hukum Sekunder

Bahan hukum sekunder merupakan publikasi tentang hukum yang bukan merupakan dokumen resmi, seperti: bukubuku teks, hasil-hasil penelitian, artikel, majalah dan jurnal ilmiah hasil-hasil seminar atau pertemuan ilmiah lainnya yang relevan dengan penelitian ini.

c) Bahan Hukum Tersier

Bahan hukum tersier atau bahan hukum penunjang yang mencakup bahan yang memberi petunjuk-petunjuk dan penjelasan terhadap bahan hukum primer dan bahan hukum sekunder, seperti kamus umum, kamus hukum, serta bahan hukum primer, sekunder dan tersier di luar hukum yang relevan dan dapat dipergunakan untuk melengkapi data yang diperlukan sperti situs website.

3. Teknik Pengumpulan Data

Teknik pengumpulan data dilakukan dengan teknik kepustakaan (library research), dengan berhubungan dengan topik penelitian ini, seperti: buku-buku hukum, majalah hukum, artikel-artikel dan bahan penunjang lainnya.

4. Analisis Data

Setelah bahan-bahan sudah diperoleh, maka analisis data dalam penelitian ini menggunakan metode pendekatan yang bersifat kualitatif, yaitu dengan mempelajari, memperhatikan kualitas dan kedalaman data yang diperoleh. Kemudian menghubungkan variabel yang satu dengan variabel yang lain sehingga dapat ditarik sebuah simpulan untuk menjawab masalah dalam penelitian ini.

\section{HASIL DAN PEMBAHASAN}

Pandangan Islam Terhadap Saksi non Muslim

Beberapa pandangan ulama menyangkut tentang saksi non muslim sebagai alat bukti di pengadilan agama. Membicarakan saksi non-muslim sebagai salah satu alat bukti di dalam persidangan, dalam hal ini ada dua hal yang perlu mendapat sorotan yaitu kesaksian nonmuslim sesama non-muslim dan kesaksian non-muslim terhadap kaum muslim. Imam Malik, Imam Syafi'iy dan imam Ahmad berpendapat bahwa kesaksian non-muslim sesama non-muslim tidak dapat diterima 
secara mutlak, baik agama mereka sama maupun agama mereka berbeda. Pendapat tersebut berdasarkan firman Allah dalam Q.S. al-Baqarah: 2/ 282, ayat tersebut mengemukakan bahwa orang yang bukan Islam, bukanlah orang yang bersifat adil dan bukan dari orang-orang yang ridha kepada kaum muslimin. Allah swt. menyifatkan mereka sebagai orang yang suka dusta dan fasik, sedangkan orang demikian itu tidak dapat dijadikan saksi. Menerima kesaksian yang dusta dan fasik, sedangkan orang Islam tidak boleh dipaksa dengan kesaksian orang kafir itu dan tidak berhak menjadi saksi sesama mereka, kalau kesaksian mereka diterima berarti sama saja dengan memuliakan mereka dan mereka mengangkat derajatnya, sedangkan agama Islam melarang yang demikian itu.

Imam Abu Hanifah dan pengikutnya mengatakan bahwa kesaksian antara nonmuslim dapat diterima, baik ia seagama maupun berbeda agama. Kesaksian kafir harbi terhadap sesamanya tidak diterima apabila negeri mereka berbeda, demikian pula kesaksian kafir zimmi yang samasama berbeda dalam suaka politik tidak dapat diterima secara mutlak. Ibnu Taimiyah berpendapat bahwa kesaksian antara sesama orang zimmi dapat diterima dengan dasar firman Allah Q.S. al-Imran: 73.

Ibnu Taimiyah mengemukakan bahwa banyak terjadi tindak pidana di antara mereka yang peristiwanya tidak disaksikan oleh orang Islam melainkan oleh kalangan mereka sendiri, kemudian mereka berperkara kepada Mahkamah Syariah. Kalau kesaksian di antara mereka ditolak oleh Mahkamah Syariah maka akan mengakibatkan mereka teraniaya dan kehilangan hak asasinya, dengan demikian akan terjadi kerusakan besar dan akan menggangu ketentraman umum. Hal ini tidak disukai oleh syariat Islam yang dianggap adil tersebut. Pendapat Ibnu Taimiyah ini banyak diikuti oleh para praktisi hukum Islam baik di Timur Tengah maupun di beberapa negara Islam lainnya.

Para ahli hukum di kalangan ulama Hanabilah membolehkan kesaksian dari saksi non-muslim atas orang-orang Islam dalam bidang wasiat apabila dilaksanakan dalam perjalanan (musafir) dan tidak ada orang lain yang dapat diangkat menjadi saksi dari kalangan orang Islam, kecuali mereka yang beragama non-muslim. Menurut ibnu Mudzin pendapat ini dipakai juga oleh Syuraih, an- Nakha'i dan alAusa't dalam memutus perkara yang diajukan kepadanya. Hanya saja meraka 
berselisih tentang pengertian non-muslim, Syuraih mengatakan bahwa hal itu hanya mencakup orang non-muslim yang ahli kitab saja, sedangkan selainnya mengatakan bahwa non-muslim di sini mencakup semua orang di luar Islam, termasuk juga orang Majusi dan penyembah berhala.

Abu Hanifah, Imam Malik, dan Imam Syafi'i menolak kesaksian orang- orang non-muslim secara mutlak, kecuali dalam hal yang sangat darurat seperti kesaksian dokter non-muslim terhadap suatu peristiwa dan kejadian. Ibnu Qayyim mengemukakan bahwa penolakan secara mutlak terhadap kesaksian nonmuslim kepada orang muslim sebagaimana yang telah dilaksanakan oleh para ahli hukum Islam sebenarnya perlu ditinjau kembali. Lebih lanjut Ibnu Qayyim mengemukakan bahwa dalam masalah persaksian yang penting adalah saksi-saksi tersebut dapat mengungkapkan tabir yang menutup kebenaran, orang- orang yang dapat mengungkapkan kebenaran itu adakalanya dari orang-orang yang bukan Islam dan orang- orang itu dapat dijamin kepercayaannya, maka dalam hal ini kesaksian dapatlah diterima. Demikain juga dalam hal pembuktian yang harus diberikan dokter yang kebetulan dokter tersebut bukan Islam, menurut Ibnu
Qayyim tidak ada salahnya untuk diterima asalkan keterangan dokter tersebut dapat dipertanggung jawabkan kebenarannya.

Pendapat Ibnu Qayyim tesebut sejalan dengan perkembangan zaman saat ini, di mana pengaruh globalisasi dunia mengakibatkan kehidupan masyarakat menjadi berbaur satu sama lain yang tidak terikat dengan satu agama saja. Apabila permasalahan di antara mereka bukanlah suatu hal yang mustahil peristiwa dan kejadian yang terjadi itu justru disaksikan oleh orang-orang yang beragama selain Islam. Para praktisi hukum di beberapa negara Islam, pendapat Ibnu Qayyim ini banyak dipergunakan dalan menyelesaikan kasus-kasus yang terjadi dalam kehidupan masyarakat. Oleh karena itu, para praktisi hukum harus dapat membedakan saksi sebagai syarat hukum atau sebagai alat pembuktian, kalau syarat hukum berkenaan dengan syarat materil dan berhubungan dengan diyanatun, sedangkan saksi sebagai alat pembuktian berhubungan dengan syarat formal yang berkaitan dengan qadhaan.

\section{Saksi Non Muslim Menurut Hukum Acara Perdata}

Kesaksian adalah kepastian yang di berikan kepada hakim di persidangan tentang peristiwa yang di persengketakaan 
dengan jalan pemberitahuan secara lisan dan pribadi oleh orang yang bukan salah satu pihak dalaam perkara, yang di panggil dalam persidangan. Jadi keteraangan yang di berikan oleh seorang saksi haruslah kejadian yang telaah dialami sendiri, sedangkan pendapat atau dugaan yang di peroleh secara berpikir tidaklah termasuk dalam suatu kesaksian. (Zainal Asikin, 2015)

Menurut A. Pitlo, kesaksian hanya boleh berisikan apa yang dilihat oleh saksi dengan panca inderanya dan tentang apa yang dapat di ketahui sendiri dengan cara demikian. Sedangkan Menurut S.M. amin, kesaksian hanya gmbaran dari apa -apa yang telah dilihat, di dengar, dan di alaminya, keterangan-keterangan ini semata-mata bersifat objektif. Kemudian menurut Sudikno Mertokuumo, kesaksian adalah kepastian yang di berikan kepada hakim di persidangan tentang peristiwa yang di persengketakan dengan jalan pemberitahuan secara lisan dan pribadi oleh orang yang bukan salah satu pihak dalam perkara, yang di panggil dalam persidangan. (Zainal Asikin, 2015)

Saksi dalam hukum acara perdata merupakan suatu alat bukti yang yang penting dalam membuktikan dalil gugatan khususnya di perdilan agama selain alat bukti tulisan maupun akta. Sebagaimana yang di tegaskan dalam dalam pasal 1895 KUH Perdata yang bunyinya adalah pembuktian dengan saksi-saksi di perkenankan dalam segala hal yang tidak di kecualikan oleh Undang-undang. Jadi, pada alat bukti menjangkau semua bidang dan jenis sengketa perdata, kecuali apabila undang-undang sendiri menentukan sengketa hanya dapat di buktikan dengan akta atau alat bukti tulisan, barulah alat bukti saksi tidak dapat di terapkan. (M. Yahya Harahap, 2005)

Menurut Pasal 1902 KUH Perdata, dalam hal suatu peristiwa atau hubungan hukum menurut Undang-undang hanya dapat dibuktikan dengan tulisan atau akta , namun alat bukti tulisan tersebut hanya berkualitas sebagai permulaan pembuktian tulisan, penyempurnaan pembuktiannya dapat ditambah dengan saksi. (M. Yahya Harahap, 2005)

Bertitik tolak Pasal dari ketentuan pasa ldari ketentuan Pasal 139-143 HIR, Pasal 165-170 RBG, pada prinsipnya menganut sistembahwa menjadi saksi dalam perkara perdata adalah kewajiban hukum, tetapi tidak imperatif dalam keadaan tertentu. Maksud tidak imperative dalam keadaan tertentu ialah saksi tidak relevan meneguhkan dalil atau bantahan, patokan ini tersirat secara a contrario (menafsirkan)dari ketentuan Pasal 139 
Anto Mutriady Lubis. Kendudukan Saksi Non Muslim Dalam Pandangan Islam dan Kitab Undang-Undang Hukum Acara Perdata Sebagai Alat Bukti Berperkara di Pengadilan Agama

ayat 1. Jika saksi yang didengar keterangannya tidak penting atau tidak berbobot untuk meneguhkan dalil penggugat atau bantahan tergugat, kepada saksi itu tidak berlaku kewajiban hukum menjadi saksi. Oleh karena itu saksi itu tidak dapat dipaksa untuk hadir dipersidangan. (M. Yahya Harahap, 2005)

Jadi secara umum, menjadi saksi dalam perkara perdata merupakan kewajiban hukum yang harus ditaati setiap orang yang cakap. Bagi yang tidak mentaatinya dapat di hadirkan dengan paksa oleh alat kekuasaan Negara. Sehingga dengan demikian bahwa saksi dalam hukum acara perdata sifatnya adalah wajib bagi siapa pun untuk di perdengarkan kesaksiannya di depan hakim dan tidak memandang adanya pembatasan terhadap agama non muslim bila yang berperkara adalah orang islam. Sesuai dengan pasal 54 Undang-Undang Nomor 3 Tahun 2006 yang sebagaimana telah di ubah dengan Undang-Undang Nomor 50 Tahun 2006 bahwasanya hukum hukum acara yang berlaku di pengadilan agama adalah hukum acara perdata yang berlaku di pengadilan umum. Sehingga kalau berpatokan pada hukum acara perdata tidak menjadi masalah bila kesaksian non muslim dalam berperkara di pengadilan agama.

\section{SIMPULAN}

Berdasarkan hasil dan pembahasan maka ditemukan pandangan Islam terhadap saksi non muslim terdapat berapa pandangan dari para ulama. Salah satu ulama yang pemikiranya tentang saksi non muslim yang di pakai Negaranegara islam adalah ibnu qayyim. Ibnu qayyim mengemukakan bahwa masalah persaksian yang penting adalah saksi-saksi tersebut dapat mengungkapkan tabir yang menutup kebenaran, orang-orang yang dapat mengungkapkan kebenaran itu adakalanya dari orang-orang yang bukan Islam dan orang-orang itu dapat dijamin kepercayaannya. Hal ini di akibatkan perkembangan zaman yang di pengaruhi era globalisasi yang mengakibatkan kehidupan masyarakat membaur satu sama lain. Sedangkan menurut hukum acara perdata tidak membatasi seseorang dari belatar belakang agama manapun untuk mejadi saksi atau sesuai dengan agama sesorang yang berperkara. Namun setiap orang yang berpikiran sehat dan sudah dewasa menjadi suatu kewajiban bagi seseorang untuk di hadirkan menjadi saksi dalam perkara di Pengadilan khususnya peradilan agama, sebagaimana dikemukakan pada Pasal 139-143 HIR/ 165-170 RBG. 


\section{DAFTAR PUSTAKA}

Asikin, Z. (2015), Hukum Acara Perdata Di Indonesia, Jakarta, Kencana.

Harahap, M. Y, (2005), Hukum Acara Perdata, Jakarta, Sinar Grafika.

Mubarak, R., \& Munawir, Z., Munthe, R, Peranan Pengadilan Agama Kelas I Medan Terhadap Pembatalan Perkawinan, Jurnal Pendidikan IlmuIlmu Sosial (JUPIIS), Volumen 8, Nomor 2, Desember 2016

Munthe, R. \& Hidayani, S., Kajian Yuridis Permohonan Itsbat Nikah Pada Pengadilan Agama Medan, Jurnal Pendidikan Ilmullmu Sosial (JUPIIS), Volumen 9, Nomor 2, Desember 2017.

Nurrudin, A. \& Tarigan, A. A. (2004), Hukum Perdata Islam Di Indonesia, Jakarta, Kencana Prnada Media Grup.

Soekanto, S. \& Mamudji, S. (2009), Penelitian Hukum Normatif; Suatu Tinjauan Singkat, Jakarta, Raja Grafindo Persada.

Somad, A. (2010), Hukum Islam/Penormaan Prinsip Syariah Dalam Hukum Indonesia, Jakarta, Kencana. 